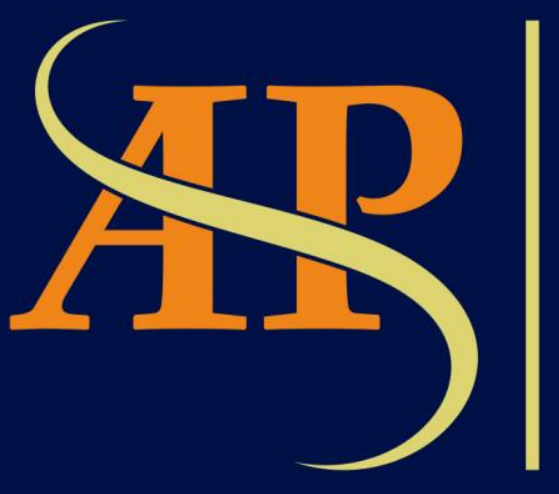

JURNAL

ASIA

PACIFIC

STUDIES

Journal of International Relations Study Program Faculty of Social and Political Sciences

Universitas Kristen Indonesia

Volume 4 | Number 2 | July - December 2020 


\title{
THE IMPLEMENTATION OF PEOPLE'S REPUBLIC OF CHINA'S MARITIME SECURITY STRATEGY TO PROTECT ITS ENERGY SECURITY IN THE INDIAN OCEAN REGION (2015-2019)
}

\author{
${ }^{1}$ Laras Lintang Kirana; ${ }^{2}$ Anak Agung Banyu Perwita \\ President Center for International Studies (PRECIS), President University, Jl. Ki Hajar Dewantara, Kota \\ Jababeka, Cikarang Baru, Bekasi 17550, Indonesia \\ banyu@president.ac.id
}

\begin{abstract}
Along with the shifting from a developing country to be a new emerging superpower country, China's economic growth and military development keep rising for the past decades. However, those make China really relies on energy security and turns into energy importer. The majority of Chinese energy is imported from the Middle East and Horn Africa and needs to be passed through the Indian Ocean. To strengthen its energy, China is building cooperation with Indian littoral states such as Pakistan, Myanmar, Bangladesh, and Sri Lanka through the initiation of Maritime Silk Road. The development of pipelines, ports, and economic corridors are expected to give China direct access to the Indian Ocean. The Indian Ocean as the home of strategic chokepoints and sea line of communications (SLOC's) also has several security issues such as piracy and external military presence that can threaten China's energy import routes and China's interests. To secure those matters, China's is applying its maritime security strategy, far seas operation strategy as well as utilizing Mahan's idea of sea power. PLA Navy deployment through the development of naval base, joint cooperation, and anti-piracy mission with the naval modernization is being done by China to secure the SLOC's and interests for its energy security in the Indian Ocean.
\end{abstract}

Keywords: energy security, Indian Ocean, Maritime Silk Road, sea lines of communications, maritime security strategy.

\begin{abstract}
Abstrak
Seiring dengan perubahan dari negara berkembang menjadi negara adikuasa baru, pertumbuhan ekonomi dan perkembangan militer Cina terus meningkat selama beberapa dekade terakhir. Akan tetapi, itu membuat Cina menjadi negara yang sangat bergantung pada keamanan energi dan berubah menjadi importir energi. Mayoritas energi Cina diimpor dari Timur Tengah dan Afrika dan perlu melewati Samudra Hindia. Untuk memperkuat ketahanan energinya, Cina membangun kerja sama dengan negara-negara pesisir Samudera Hindia seperti Pakistan, Myanmar, Bangladesh, dan Sri Lanka melalui inisiasi Jalur Sutera Maritim. Pengembangan jalur pipa energi, pelabuhan, dan koridor ekonomi diharapkan memberi Cina akses langsung ke Samudra Hindia. Samudera Hindia sebagai alur laut dan jalur komunikasi laut yang strategis juga memiliki beberapa masalah keamanan seperti pembajakan dan kehadiran militer dari aktor eksternal yang dapat mengancam rute impor energi dan kepentingan Cina. Untuk mengamankan hal-hal tersebut, Cina menerapkan strategi keamanan maritim, far seas operations serta menggunakan ide dari Mahan dalam memanfaatkan kekuatan lautnya. Penempatan Angkatan Laut Cina melalui pengembangan pangkalan angkatan laut, latihan bersama, dan misi anti-pembajakan dengan modernisasi angkatan laut dilakukan oleh Cina untuk mengamankan jalur komunikasi laut dan kepentingan Cina dalam keamanan energinya di Samudra Hindia.
\end{abstract}

Kata kunci: ketahanan energi, Samudera Hindia, Jalur Sutera Maritime, jalur komunikasi laut, strategi keamanan maritim. 


\section{Introduction}

The rise of China's shifting from a developing country to new emerging superpower country has always been an interesting subject to study. Especially with the rapid economic growth and military development each year, makes this country always overshadowed with energy security to continue the growth of the nation. More than 60 percent of China 's imported energy supplies are transported through shipping lanes in the Indian Ocean Region (Hannah, 2019). According to Donna Nincic, there are two threats to energy security, which are threat to the supply of oil and natural gas and threat to energy infrastructure, especially transportation. When all these problems combine and pose a threat to commercial shipping, they also pose a threat to security of access to energy (Nincic and Donna). Affirmed by David Zweig and Bi Jianhai, "Securing China's energy needs does not just revolve around obtaining them, but more importantly, the ability to get them home safely." (Zweig and Jinhai, 2009). In this context, the availability of resources and the safety of transportation routes have become the concern of the Chinese government to secure its energy security.

The Middle East and Africa are indeed the major suppliers of Chinese oil through Indian Ocean. Thus, China places a priority on establishing strong ties with Indian Ocean Region countries through the initative of Maritime Silk Road and military footprints in order to secure the routes in Indian Ocean (Brewster and David, 2018). Securing the energy while protecting the SLOC's become the vital sectors for China as stated in the 2015 China Defense White Paper,

"With the growth of China's national interests, its national security is more vulnerable to international and regional turmoil, terrorism, piracy, natural disasters and epidemics, the security of overseas interests concerning energy and resources, strategic SLOC's, as well as institutions, personnel and assets abroad, has become an imminent issue." (Ministry of National Defense of the People's Republic of China, 2015).

The situation of an anarchist in the international political stage where the struggle for power is being carried out by big countries makes China apply maritime security strategy which is far seas operation with the utilization of comprehensive defense support, PLA Navy (The State Council Information Office of the People's Republic of China, 2015). China's maritime security strategy direction towards the Indian Ocean Region in terms of energy security can be understood as an effort to gain power in controlling energy and securing the SLOC's is quite distinct. In the Indian Ocean Region, the Chinese government deploys its navy power along strategic lines. China places a number of military forces and sophisticated military equipment in sea-lines and ports that connecting the Indian Ocean to China's mainland through special economic zones (Sinchun Wu, 2018).

This paper explicates how China implements its maritime security strategy to protect energy security in the Indian Ocean Region. The timeline of the paper limited to 2015-2019 as Chinese oil consumption and import is increasing and China was also massively expanding economic, political-diplomatic and military presence in the Indian Ocean Region during those years.

\section{The Strategic Importance of the Indian Ocean Region (IOR) for Major Powers and China's National Interests in the Indian Ocean Region}

Ocean has always been an arena to show the interests as well as the powers of the countries in international theatre. The Indian Ocean is one of the strategic areas in the world with a variety of trading and shipping activities that cross the region. Not only that, but the Indian Ocean also becomes home to natural resources such as oil, natural gas, noble metals, 
and fisheries. Moreover, the Indian Ocean is also home to several important chokepoints that show in figure 1. Considering the Indian Ocean as a maritime domain that has strategic trade routes and key channel around the area, security challenges in the Indian Ocean have shown a complex threat increase in recent years, including traditional and non-traditional threats. The threats across the Indian Ocean involves dangerous activities such as piracy and maritime terrorism that have the potential considerable impacts on security with a synergistic effect in worsen the inter-state conflict and non-state political violence (Michel at el. 2012). Thus, the enormous opportunities and security challenges in the Indian Ocean make some countries that have access to the region will continue to make efforts to achieve their interests and maintain their security (Albert and Elyeanor). Recalled what Alfred Tayer Mahan said, "whoever achieve the maritime supremacy in the ocean, they would be prominent player in the international scene." (Mahan and Alfred, 1918). Likewise, the Indian Ocean becomes a strategic geopolitical area in $21^{\text {st }}$ century seeing that some major countries such as: India, the U.S, China, Australia, Japan are trying to control the area.

\section{Image. 1 Maps of the Indian Ocean}



Source: www.sipri.org/news/2018/new-report-21st-century-maritime-silk-road

Along with its status as a new superpower, China has the ambition to become the largest maritime power in the world as part of national interests. This was conveyed by President Xi Jinping formally at the 19th congress of the Chinese Communist Party (CPC) by stating that realizing China as a world maritime power and protect China's foreign interest are the vision of the Chinese Communist Party (Baziniz, 2017). Not only presence militarily in the South China Sea and the Pacific Ocean, but China also expands its maritime power in the Indian Ocean.

The Indian Ocean is a strategic SLOCs for China's interests, in addition to supporting the economy, it is to solidify China's steps as maritime power. The Indian Ocean for China also would be the path to for energy route. To support that, China is also building several projects and ports with countries around the coast (Arlington and Isaac, 2015). As the Chinese economy is growing, so does China need energy and natural resources. This prompted when China establishes the strategic steps of the Indian Ocean region as an area rich in energy and natural resources, as well as the historical track of the imperial glory of China in trading activities in the Maritime Silk Road (Arlington and Issac, 2015).

To protect interest and prevent other countries become threats to China, China is also growing its naval presence including monitoring Indian and American military development in 
the Indian Ocean. It cannot be denied if the Indian Ocean becomes power competition arena for major powers. However, China's efforts to keep dominating and influencing the Indian Ocean Region will keep going on. China builds strategic partnerships such as building commercial ports or even the naval base with some countries starting from Pakistan, Myanmar, Djibouti, Bangladesh, and Sri Lanka (Dutta and Sujit, 2019).

\section{China's Energy Security}

To further develop the country, China needs a large amount of energy. It cannot be denied if year by year China will continue to experience an increase in energy consumption (CSIS, 2018). Table 1 illustrates how in 2008 China's primary energy (coal, oil, natural gas, etc) consumption reached 2.230 million metric tons and a decade later its increased $45 \%$ and China reached 3.273 million metric tons in 2018 (British Petroleum, 2019). China is not a country that can't produce energy. However, with the increase in the number of energy consumption, China's energy production no longer can fulfil the energy need. Thus, it is resulting in China's dependence on energy import from other regions (CSIS, 2018), it can be seen in graph 7 that the number of China's oil imports is also reported $50 \%$ increase from 6.177.503 barrel per day in 2014 to 9.261.414 barrel per day in 2018 (CEIC Data, 2018).

Table. 1 China's Primary Energy Consumption

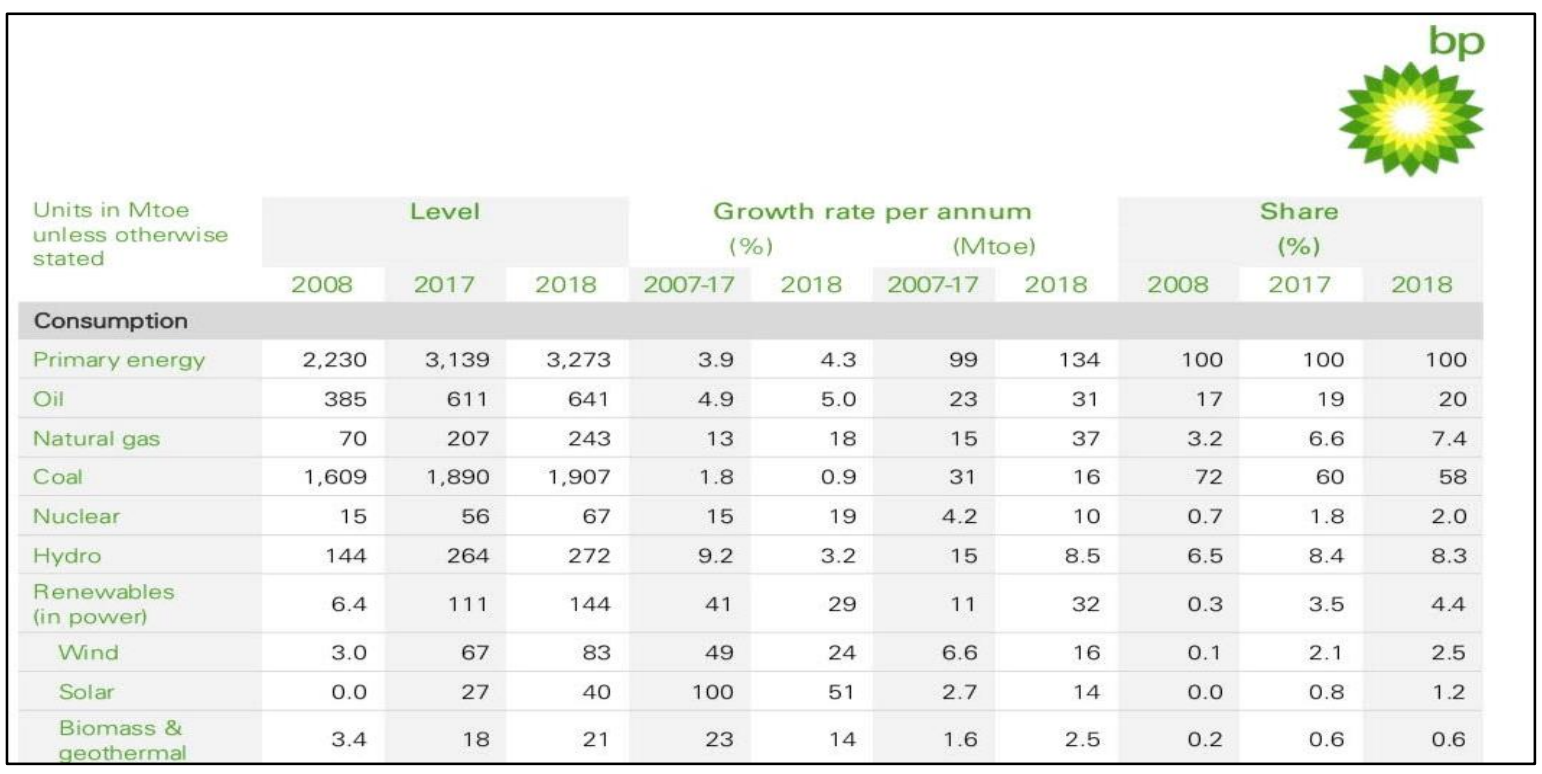

Source: British Petroleum Statistical Review 2019 
Table. 2 China's Crude Oil Imports

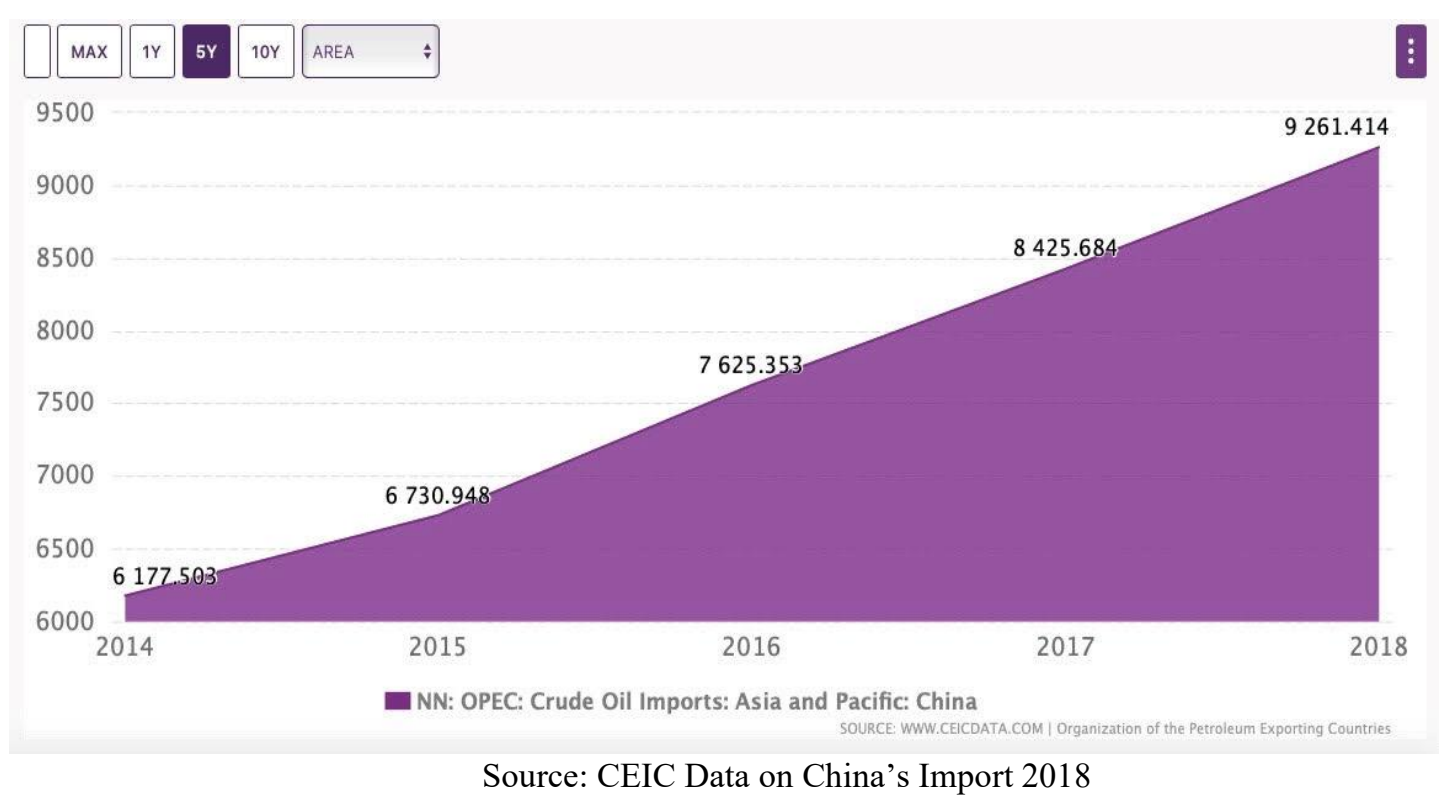

Mehdi P. Amineh and Yang Guang argued that one of the challenges in China's energy security is the increasing dependence on imports from foreign markets (Amineh and Guang, 2012). According to Chinese National Petroleum, more than $70 \%$ China's oil supply came from import, especially from the Middle East and African countries (Shuo and Zou, 2018). With high dependence on shipping lines in the territorial waters that connect China with Africa and the Middle East also poses a high risk to China's energy security. The potential energy challenges for China are not only related to access to energy producers, but also the security of the world's energy transportation routes (Gordon and Matthew, 2016). The security challenges in the energy route in the Indian Ocean can be such as maritime terrorism, piracy, and smuggling can pose a threat to hostilities, shipping accident, or even disastrous oil spill. Moreover, much of China's oil is traveling from politically unstable region that can also pose a threat to security of access to energy (Luft and Gal, 2009). This, of course, requires security along the shipping line. In which, China's energy security will be threatened because when transportation routes are disrupted, supply will be hampered (Leung et al. 2013).

Then, in the effort of achieving energy security, China does not only stop at importing energy, but also how to bring it safely to China. This becomes very important considering the issue of China's energy security route has been colored by potential traditional and nontraditional security challenges and geopolitical rivalry between the USA, China-Pakistan vis-àvis India, and other regional actors in the Indian Ocean (Smith and Jeff, 2013). Building cooperation through Maritime Silk Road is one way out for China to overcome the security problems of its energy supply transportation lines.

The Maritime Silk Road is actively involving in projects and plans to build ports, channel improvement, and other infrastructure projects. China plays a role in securing energy routes by investing. A large investment has been made to facilitate the port in other planned locations. As it is illustrated in figure 2, ports become a getaway of the country, sea transport network for foreign trade, and transit area. By developing ports in neighboring countries, such as Gwadar Port in Pakistan, Hambantota in Sri Lanka, Chittagong in Bangladesh, and Kyaukhphyu in Myanmar, China has more easily placed control over energy transportation routes at sea and on land. By developing ports, China is also increasing the dependency of Indian Ocean countries towards China by making investment and providing development support for them (Stockholm International Peace Research Institute, 2018). From that, it is 
considered that the challenges facing China in energy security are not only limited to the availability of energy supplies, but also in securing the guaranteed access of energy import so it can arrive safely to the mainland and help China to boost its economic growth and military development.

\section{Image. 2 China's Port in the Indian Ocean}

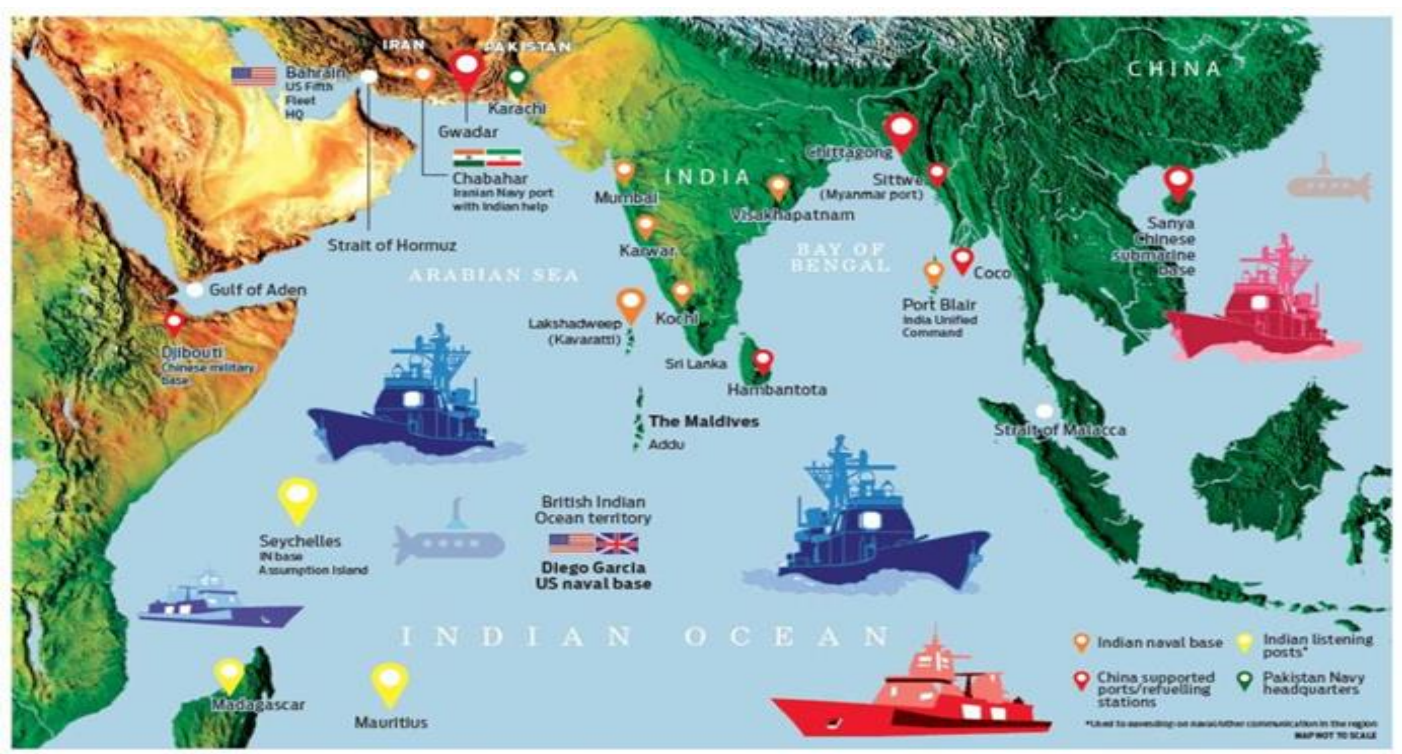

Source: www.hitbrother.com/chinese-military-bases-in-the-indian-ocean-region-ior/

\section{The Implementation of People's Republic of China's Maritime Security Strategy to Protect Energy Security in the Indian Ocean Region}

China has been experiencing the changing of its maritime security strategy for these past decades. During Mao Zedong era China adopted near coast defense, then in the 1980s it changed to near-seas active defense, then at the latest, it turns into a far seas' operation. According to China's Defense White Paper 2015, the strategy of open seas / far seas protection along with a modern navy force will be used by China to protect overseas interests (Ministry of National Defense of the People's Republic of China, 2015). In addition China's Defense White Paper 2019 also stated,

"PLA Navy is speeding up the transition of its tasks from defense on the near seas to protect missions on the far seas, and growing its capabilities for maritime maneuver operations, maritime joint operations, strategic deterrence and counterattack, comprehensive defense, and support to build strong and modernized naval force."

( The State Council Information Office of the People's Republic of China, 2019).

It means far seas operation strategy that was being used by China would refer to have operation in broader and further areas such as South Pacific, Indian Ocean, and Gulf waters. This strategy allows PLA Navy to operate further areas of 1000 nautical miles from its territory. However far seas operation would require better technology on China's weapons and personnel or known as military modernization. China's maritime interest and the implementation of far seas operation to protec its overseas interest can be seen on how China expanding its global navy operation such as the establishment of Djibouti naval base as PLA Navy's first overseas military base with the deployment of personnel and equipment. Then PLA Navy China also has conducted some far seas operation in several countries since 2008 such as port calls and visit in several countries, joint navy exercises with IOR countries, anti-piracy operations in the Gulf 
of Aden, and HADR mission (humanitarian assistance and disaster relief) in Yemen conflict (Defense Intelligence Agency).

\subsection{Naval Visit}

Sea engagement with other navy is crucial for building a positive image of China in growing maritime presence in the Indian Ocean. The engagement can be seen in how PLA Navy doing port calls and visits in the Indian Ocean littoral states during these years (Andrew and Austin, 2016). For example, in May 2016, PLA Navy ship arrived in the South Africa to did naval visit. During the naval visit, PLA Navy also conducted friendly exchange with South Africa navy including joint exercise in South Africa's coastal waters (Embassy of the People's Republic of China in Republic of South Africa, 2016). In recent years, PLA Navy also was conducting naval visit after did anti-piracy task mission in the Gulf of Aden. For example, $30^{\text {th }}$ group task 539 visited Cambodia in 2018 (Regarda and Helena, 2019).

Following in 2019, $31^{\text {st }}$ group task 998 has also visited Sydney for four days. Prime Minister Scott Morrison stated that the naval visit was a reciprocal visit to see each other host on each navy's vessels (Kuper and Stephen, 2019). Furthermore, table 3 (below) illustrates that from 2003 to 2018 China has done naval port visit to several Indian Ocean countries such as Oman 25 times, Djibouti 25 times, Pakistan 12 times, Thailand 11 times, Singapore 9 times, Sri Lanka 9 times, Australia 8 times, Saudi Arabia 8 times, Indonesia 7 times, Malaysia 7 times, Bangladesh 6 times, South Africa 6 times, Myanmar 4 times, Mozambique 2 times, Kenya 2 times, and Maldives 1 time (Duchâtel et al. 2018).

Table. 3 Chinese Naval Port Visits (2003-2018)

\section{Chinese naval port visits (2003-2018)}

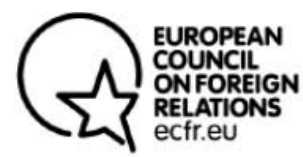

\begin{tabular}{|l|c|}
\hline Countries & Naval port calls \\
\hline Oman & 25 \\
\hline Dijbouti & 23 \\
\hline Pakistan & 12 \\
\hline Yemen & 11 \\
\hline Thailand & 10 \\
\hline United States, Singapore, Sri Lanka & 9 \\
\hline Australia, Saudi Arabia & 8 \\
\hline New Zealand, Indonesia, Malaysia & 7 \\
\hline Bangladesh, India, South Africa, Russia & 6 \\
\hline France, Philippines, Vietnam & 5 \\
\hline Greece, Myanmar, United Kingdom & 4 \\
\hline Algeria, Cambodia, Egypt, Germany, Italy, Portugal, Seychelles, S Korea, Turkey & 3 \\
\hline $\begin{array}{l}\text { Angola, Brazil, Canada, Chile, Cuba, Denmark, Ecuador, Fiii, Finland, Kenya, Mexico, } \\
\text { Mozambique, Peru, Qatar, Sierra Leone, Sweden, Tanzania, Ukraine, UAE }\end{array}$ & 2 \\
\hline $\begin{array}{l}\text { Argentina, Belgium, Brunel, Bulgaria, Cameroon, Congo, Costa Rica, Croatia, Latvia, Gabon, } \\
\text { Nigeria, N Korea, Papua New Guinea, Poland, Romania, Sudan, Tunisia, Trinidad \& Tobago }\end{array}$ & \\
\hline
\end{tabular}

Source: www.ecfr.eu/publications/summary/blue_china_navigating_the_maritime_silk_road_to_europe 


\subsection{Anti-Piracy Operations}

The sea route that is connecting China with the Middle East and Africa passes through dangerous waters. China's energy shipping and security depend on a secure waterway that connect China with its energy exporter. If a threat arises where China cannot access the Gulf of Aden, which also includes the Suez Canal and the Red Sea, it would certainly harm China's energy security (Erickson, 2016). The Gulf of Aden is known as a piracy-prone area that can pose a threat to China's shipping activities from Africa and Middle East in this route. Some Chinese ships have been victims of piracy in there. For example, Tanyo No. 8, hijacked by Somali pirates in November 2008, in the Indian Ocean off the coast of Kenya and taken to the Somali port city of Kismayo, near the Kenyan border. Then in May 2011, the Chinese cargo ship, MV Full City, with 24 crew members, was also surrounded by Somali pirates around 450 nautical miles west of Karwar in Karnataka in the Arabian Sea (Venkataraman \& Manickam, 2016). Learning from the experiences, since 2008 China has been starting to have anti-piracy operations in the Gulf of Aden and its surroundings. Anti-piracy operations have been being a springboard for China to secure energy route in sea lifeline while expanding its maritime security operations in broader range. Moreover, the presence of PLA Navy in the Gulf of Aden will also become Chinese way to achieve its burgeoning overseas interests. From 2015 until now PLA navy has been doing fourteen anti-piracy operations (Ministries of National Defense of the People's Republic of China, 2016).

\subsection{Chinese Naval Base Development in Djibouti}

"Through friendly consultations between China and Djibouti, the two sides have reached consensus for

China to build support facilities in Djibouti. The facilities will be used for logistical support and personnel recuperation of the Chinese armed forces conducting such missions as maritime escort in the Gulf of Aden and Somali coast, peacekeeping, and humanitarian assistance. Currently, construction of infrastructure for the support facilities has started, and China has deployed personnel in Djibouti for doing tasks." (Ministry of National Defense of the People's Republic of China, 2016).

In February 2016, Colonel Wu Qian, Spokesman of the Ministry of National Defense of the People's Republic of China announced that the development of Chinese Naval Base in Djibouti has just already started (Ministry of National Defense of the People's Republic of China, 2016). Following a statement from Hong Lei, Spokesman of the Ministry of Foreign Affairs of the People's Republic of China that China built a military base in Djibouti in order to support regional peace and provide logistics facilities. A naval base in Djibouti will be used to handle large commodities, containers, and other goods, accommodate up to several thousand troops and weapons storage, ship and helicopter repair facilities, commercial ships as well as military ships, and to support anti-piracy mission in the Horn of Africa and the Middle East (Ministry of Foreign Affairs of the People's Republic of China, 2016).

Seeing from figure 3 (below) Djibouti is located in the accrossed Gulf of Aden and the Red Sea makes Djibouti has a strategic location for some regional powers in the Indian Ocean such as the USA, Japan, and France. There are Naval Camp Lemonnier of the USA, Les Forces Françaises Stationnées à Djibouti (FFDj) owned by France, and Japan's Maritime Self-Defense Forces (MSDF) (Pike and John, 2018). Djibouti offers favorable options for China for number of important reasons, such as important strategic locations, good economic prospects, and good domestic stability in areas of severe instability. Djibouti's location which is close to conflicting areas such as Somalia, Nigeria, Yemen, Libya, Iraq, South Sudan and others where there are Chinese interests in the region can make it easier for China to enhance its PLA Navy's ability to secure China's energy route and maritime interest in the Indian Ocean especially around the Middle East and Africa (Melvin and Neil, 2019). 
Image. 3 Chinese Naval Base in Djibouti

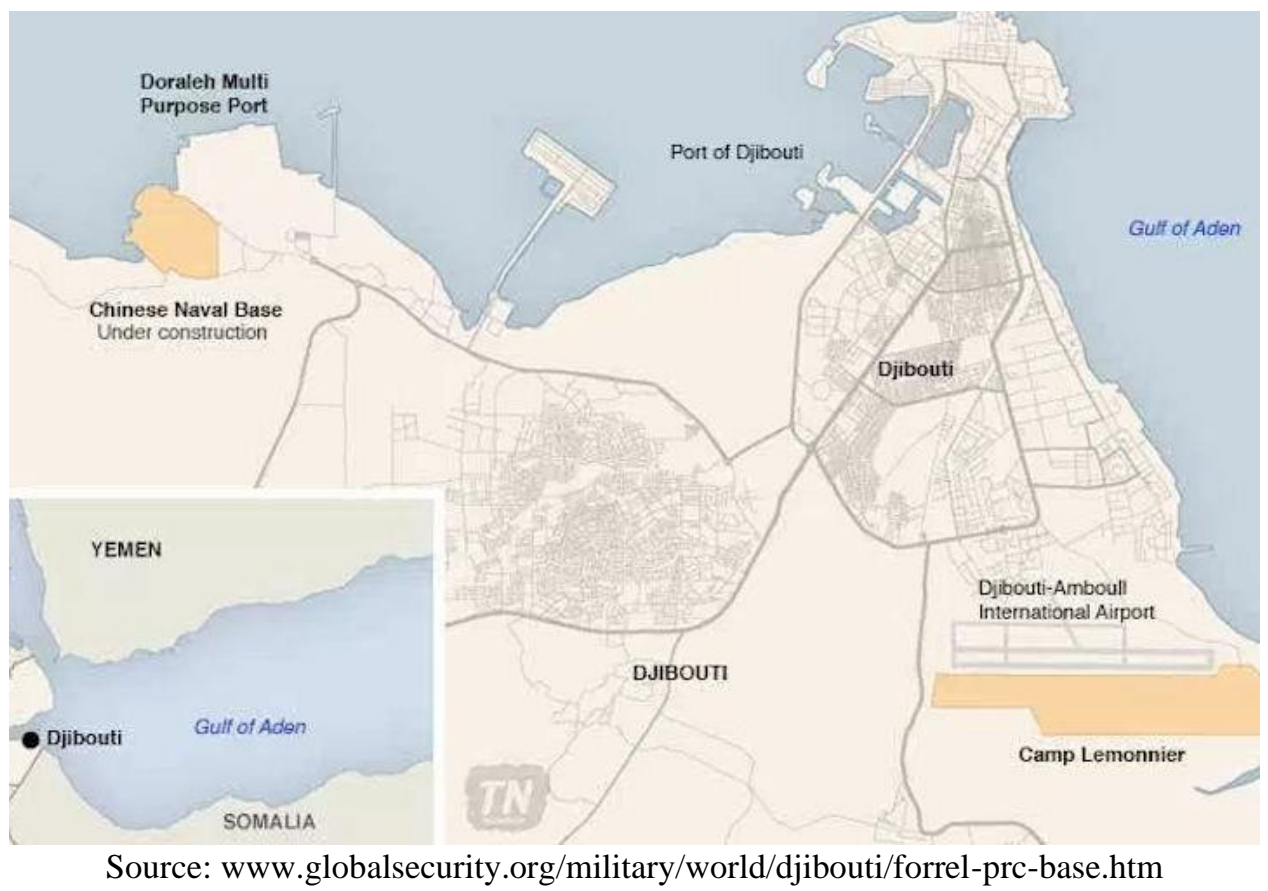

\subsection{Maritime Cooperation with Indian Ocean Countries \\ - China - Pakistan}

Since 2003 China and Pakistan have been doing naval exercise, thus Pakistan became the first PLA Navy partner to have bilateral naval exercise. In 2014, China and Pakistan conducted joint exercise series for the next several years. First in 2014 it was conducted in Pakistani waters around the North Arabian Sea. In 2015, its continue to be conducted in the East China Sea. In early and the end of 2016, it was held twice in the North Arabian Sea. In 2017 it was conducted in Shanghai (The Nation, 2017).

Maritime cooperation that Pakistan and China have is not only about securing the strategic port and joining naval exercise. China also becomes Pakistan provider to enhance its naval power. In 2015 Pakistan signed an agreement with China Shipbuilding Industry Corporation for purchasing six patrol boats of 600ton and 1500ton. Following in 2016, Pakistan also signed a deal to purchase eight submarines that worth $\$ 6$ billion from China (Calvo and Alex, 2016). As a result of win-win maritime cooperation for both countries, while Pakistan provide a strategic location for China to secure its energy and maritime routes as well as China's eye to observe India naval activities in the Indian Ocean, China also gives major naval supplies and help Pakistan to develop its naval force (Collin and Koh, 2016).

- China - Myanmar

Collin Koh, a maritime security expert, argues that Myanmar has strategic locations for China as some regions in Myanmar can offer alternative routes for China's import on oil and gas supply which come from the Middle East and Africa (Lo and Kinling, 2017). Indeed it's true because Myanmar can give China access to secure maritime space in the Bay of Bengal and the Andaman Sea that is very crucial in the Indian Ocean. However, China is also considering Myanmar will give help to China for countering India's regional influence since the Bay of Bengal and the Andaman Sea are India's backyards (Yonghong et al. 2014).

Since 1988 China has gradually become the largest supplier for Myanmar military stuff including ship and assistance Tatmadaw with enhanced capability of military stuff and personnel (Shivananda, 2011). Joint naval exercise also has been done by PLA Navy since 
2010. In August 2010 after had anti-piracy mission in the Gulf of Aden. PLA Navy with Tatmadaw Navy in order to enhance the naval capability in the Bay of Bengal (Shivananda, 2011). Following in May $21^{\text {st }} 2017$, China and Myanmar conducted naval exercise in the Gulf of Martaban, Andaman Sea. Its participated by Chinese guided-missile destroyer, guidedmissile frigates, comprehensive supply ship, Myanmar's guided-missile frigate, and guidedmissile corvette (Parameswaran and Prashanth, 2018).

In September 2016, PLA Navy $23^{\text {rd }}$ Group Task 531 conducted port call in Myanmar Port. Then in May 2018, PLA Navy also conducted port call in Thilawa. There were three Chinese warships, Changchun, Jingzhou, and Chaohou with other Myanmar naval officials did friendship call to enhance capability exchange and mutual trust (Xinhua, 2017).

\section{- China - Bangladesh}

China's interest in the Indian Ocean will continue to push China to establish maritime cooperation with countries around there. Bangladesh, a country that is lying on the Bay of Bengal, the northern part of the Indian Ocean seems attractive to China in expanding its naval footprint. In this regard, Bangladesh also can get mutual benefit from regional maritime player such as China to achieve its Forces Goal 2030 that one of the missions is to augment Bangladesh's naval capabilities (Samaranayake and Nilanthi, 2016).

According to Finnigan, Bangladesh Prime Minister Sheikh Hasina is now trying to capitalize on the geopolitical advantage that Bangladesh has as a country that is located in the Indian Ocean SLOCs that can link China to the Arabian World and the Horn of Africa, which have an important role in securing energy supplies for Beijing. Moreover, Chittagong Port is considering to be dual-use as port and naval base for both China and Bangladesh in the future (Finnigan and Christopher, 2019).

Enhancing Bangladesh's naval capabilities also becomes China's necessity to keep growing maritime presence in Bangladesh. From 1980s Bangladesh navy has been equipped by China frigates and missile boats. And in March 2017, Bangladesh purchased two Ming-class boats from China. With China's help, Bangladesh is also developing a new submarine base in Cox's Bazar (Davis and Anthony, 2020). It can be seen in figure 4 (below), Cox's Bazar is located near the maritime border between Bangladesh and Myanmar. In Rakhine State, there is Kyaukpyu Port that is also being developed by China. Growing China's maritime presence between Bangladesh and Myanmar in the long-standing Bangladesh - Myanmar maritime boundary dispute will open up a new possibility of peaceful resolution for both countries. As China's State Councilor, Wang Yi stated "As a friend of China and Bangladesh, China will provide peace assistance within the capacity.” (Xinhua, 2019).

Figure 4: Maps of Maritime Border between Bangladesh and Myanmar

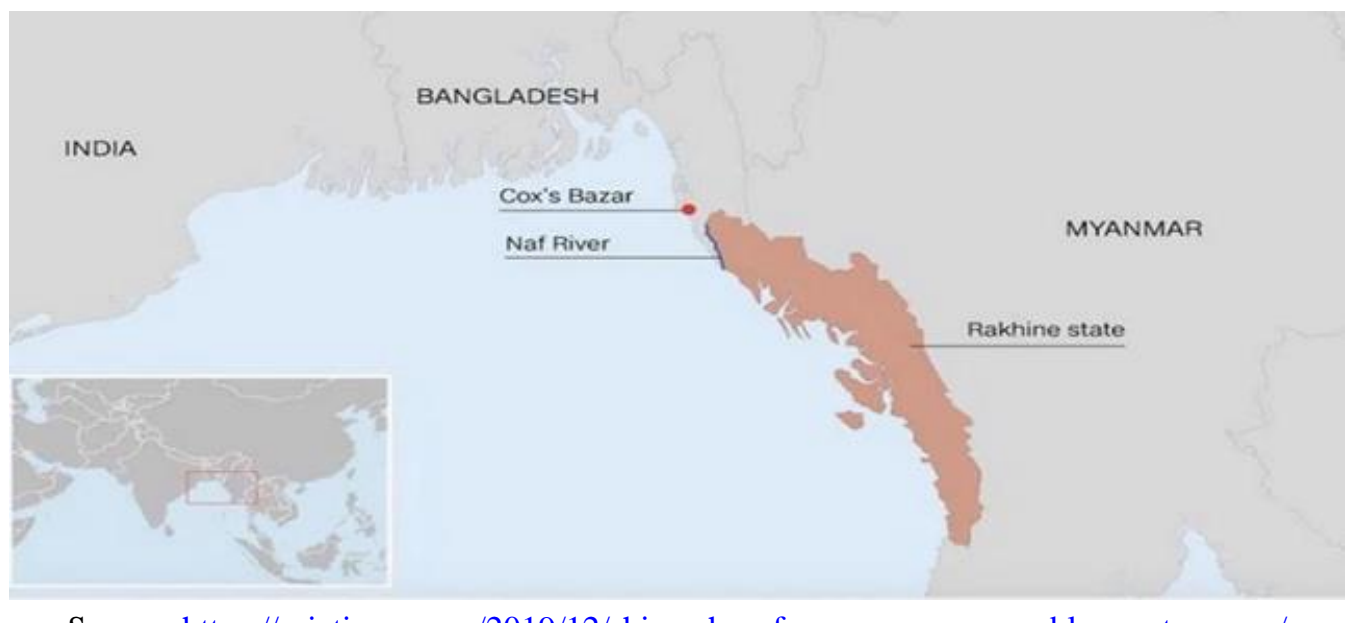

Source: https://asiatimes.com/2019/12/ships-ahoy-for-myanmars-new-blue-water-navy/ 


\section{Conclusion}

The rise of China in this $21^{\text {st }}$ century always be a great geopolitics topic to discuss. China's rise in the economic growth and military development has made China become the new emerging superpower. Although, it has made China also become very dependent on the availability of energy. China is not a country that can't produce energy, still and all China's energy consumption is increasing year by year. Thus, it requires China to have energy import from oil large reserve countries, especially from the Horn of Africa and the Middle East. Most of the oil sources from Africa and the Middle East need to pass the Indian Ocean. The Indian Ocean is not only ocean that is filled by the fish, but the Indian Ocean also provides wealth of oil, marine resources, and minerals. Moreover, the Indian Ocean has always been being home of SLOCs and chokepoints for other major powers such as Australia, India, Japan, and the USA. In order to maintain energy security, it is important for China to secure the SLOCs in the Indian Ocean.

As a matter of fact, China is not located in the Indian Ocean. Still, to keep increasing China's presence in the Indian Ocean, China is building cooperation through the initiative strategy of Maritime Silk Road with the Indian Ocean littoral states such as Pakistan with Gwadar Port, Sri Lanka with Hambantota Port, Bangladesh with Chittagong Port, and Myanmar with Kyaukpyu Port. Those countries are expected to give China direct access to the Indian Ocean while building ports, pipelines, special economic corridors for the energy route to reach China's mainland. However, as the energy security concept conveyed that energy security is not only limited to the availability of energy supply, but also in the security and safety of getting energy sources. This is important considering the threat such as piracy, maritime terrorism, and power competition of major powers that can disrupt China's energy security can happen anytime in the Indian Ocean waters.

Realizing the importance of the Indian Ocean, China is applying its maritime security strategy which is far seas operation as well as utilizing its sea power to protect its interests. China believes in the idea of Alfred Tayer Mahan which is sea power. Seapower is believed to become the instrument of a country to achieve its national interests such as political, economic, and military by using navy to control the sea. In carrying out its sea power's presence in the Indian Ocean, PLA Navy is building China's first overseas naval base in Djibouti, doing antipiracy mission and naval visits, and having maritime cooperation with littoral states.

It is undeniable that China will keep needs energy import from the Middle East and Africa that needs to pass through Indian Ocean SLOCs. In addition, China's initiative of Maritime Silk Road by influencing Indian Ocean littoral states also will be continued. Despite of that, threats can appear at any time and anywhere in the Indian Ocean. It can be stated that China is applying far seas operations while utilizing Mahanian way of sea power utilization in attempt to gain influence, protect the interests, as well as secure the SLOCs for its energy security towards the Indian Ocean. 


\section{REFERENCES}

\section{Books}

Amineh, M. P., and Guang Yang. Secure Oil and Alternative Energy: The Geopolitics of Energy Paths of China and the European Union, 26. Leiden: Brill, 2012.

Erickson, Andrew S., and Austin M. Strange. Six Years at Sea... and Counting: Gulf of Aden Anti- Piracy and China's Maritime Commons Presence. Washington D.C: Jamestown Foundation, $2016.2 \quad$ http://www.andrewerickson.com/wpcontent/uploads/2015/11/Erickson-Publication_Anti-Piracy_China_JamestownBook_GoA-Mission_6-Years_2015_Final.pdf.

Leung, Guy C., Aleh Cherp, Jessica Jewell, and Yi-Ming Wei. Securitization of Energy Supply Chains in China. Amsterdam: Elsevier Ltd, 2013. PDF.

Mahan, Alfred T. The Influence of Sea Power Upon History, 1660-1783. Gretna: Pelican Publishing, 1918. pdf.

Michel, David, Henry L. Center, Rupert Herbert-Burns, Caitlyn Antrim, Halae Fuller, and Lindsay Dolan. Indian Ocean Rising: Maritime Security and Policy Challenges, 23. Washington DC: Stimson, 2012. pdf.

Smith, Jeff M. Cold Peace: China-India Rivalry in the Twenty-first Century, 148. Maryland: Lexington, 2013. PDF.

\section{Journals}

China Military. "Escort Missions." China Military. Last modified 2019. https://eng.chinamil.com.cn/china-military/node_83426.htm.

Collin, Koh Swee L. "China and Pakistan Join Forces Under the Sea." The National Interest. Last modified January 6, 2016. https://nationalinterest.org/feature/china-pakistanjoin-forces- under-the-sea-14829.

Davis, Anthony. "Ships Ahoy for Myanmar's New Blue-water Navy." Asia Times. Last modified February 18, 2020. https://asiatimes.com/2019/12/ships-ahoy-formyanmars-new-blue-water- navy/.

Lo, Kinling. "China Eyes Closer Military Cooperation with Myanmar." South China Morning Post. Last modified November 2017. https://www.scmp.com/news/china/diplomacy- defence/article/2121298/chinaeyes-closer-military-cooperation-myanmar-it-looks.

Parameswaran, Prashanth. "China Holds First Naval Exercise with Myanmar." The Diplomat. Last modified July 8, 2018. https://thediplomat.com/2017/05/china-holds-firstnaval-exercise-with- myanmar/.

Shuo, Zou. "Crude Imports to Increase 7.7\%." China Daily. Last modified January 17, 2018. http://www.chinadaily.com.cn/a/201801/17/WS5a5e8b3ea310e4ebf433e29a.html.

The Nation. "Pakistan, China Hold Joint Navy Exercise." The Nation. Last modified December 10, 2017. https://nation.com.pk/10-Dec-2017/pakistan-china-hold-joint-navyexercise.

Venkataraman, Manickam. "Piracy off the Coast of Somalia: Implications for China's Maritime Security." Journal of the Global South 3, no. 5 (2016). https://link.springer.com/content/pdf/10.1186/s40728-016-0034-1.pdf.

Xinhua. "Chinese Naval Fleet Calls at Myanmar Port to Enhance Exchange." Xinhua. Last modified May 18, 2017. https://www.xinhuanet.com//english/201705/18/c_136294909.htm. 
Xinhua. "China to Enhance Cooperation with Myanmar, Bangladesh to Resolve Rakhine Issue." Xinhua. Last modified September 24, 2019. https://www.xinhuanet.com/english/2019- 09/24/c_138418279.htm.

Zweig, D., \& Jinhai, B. (2009, January 28). China's Global Hunt for Energy. Retrieved from https://www.foreignaffairs.com/articles/asia/2005-09-01/chinas-global-hunt-energy

\section{Websites}

Albert, Eleanor. "Competition in the Indian Ocean." Council on Foreign Relations. Last modified May 19, 2016. https://www.cfr.org/backgrounder/competition-indian-ocean. https://ses.library.usyd.edu.au/bitstream/handle/2123/16146/Cribb\%20\&\%20Ford\%20 Indonesia\%20as\%20an\%20Archipelago.pdf;jsessionid=AAD171D717BFE10FB49A D2D2713D587F ?sequence=2.

Arlington, Isaac B. "China's Maritime Rights and Interests: Organizing to Become a Maritime Power." Paper presented at CNA Conference, Arlington, July 29, 2015.

Brewster, David. "China's Play for Military Bases in the Eastern Indian Ocean." Lowy Institute. Last modified May 15, 2018. https://www.lowyinstitute.org/the-interpreter/china-splay-military- bases-eastern-indian-ocean.

British Petroleum. "BP Statistical Review - China." British Petroleum. Last modified 2019. https://www.bp.com/content/dam/bp/business-sites/en/global/corporate/pdfs/energyeconomics/statistical-review/bp-stats-review-2019-china-insights.pdf.

CEIC Data. "China Crude Oil: Imports." Global Economic Data, Indicators, Charts \& Forecasts I CEIC. Last modified December 31, 2018. https://www.ceicdata.com/en/indicator/china/crude- oil-imports.

Calvo, Alex. "Pakistan's Navy: A Quick Look." Center for International Maritime Security. Last modified March 23, 2016. https://cimsec.org/pakistans-navy-quick-look/23227.

Defense Intelligence Agency. "PLA Navy." In China Military Power; Modernizing a Force to Fight and Win. Washington D.C: Defense Intelligence Agency, 2019. https://admin.govexec.com/media/gbc/docs/pdfs_edit/dod-2019-

Duchâtel, Mathieu, and Alexandre S. Duplaix. "Blue China: Navigating the Maritime Silk Road to $\quad$ Europe." European Council on Foreign Relations. Last modified April 23, 2018. https://www.ecfr.eu/publications/summary/blue_china_navigating_the_maritime_silk_ road_to__europe.

Dutta, Sujit. "China's Emerging Power and Military Role: Implications for South Asia." RAND Corporation Provides Objective Research Services and Public Policy Analysis. Accessed December 15, 2019. https://www.rand.org/content/dam/rand/pubs/conf_proceedings/CF137/CF137.chap5. pdf.

Embassy of the People's Republic of China in Republic of South Africa. China Navy Ships Arrive in South Africa for Friendly Visit. Capetown: Embassy of the People's Republic of China in Republic of South Africa, 2016. https://za.chinaembassy.org/eng/zngx/zzgx/t1364056.htm.

Finnigan, Christopher. "Bangladesh-China Relations Have Metamorphosed into a Strategic Partnership." South Asia @ LSE. Last modified June 20, 2019. https://blogs.lse.ac.uk/southasia/2019/06/20/bangladesh-china-relations-havemetamorphosed- into-a-strategic-partnership/.

Gordon, Matthew C. "Securing the Energy Supply: China's 'Malacca Dilemma?" EInternational Relations. Last modified February 26, 2016. https://www.eir.info/2016/02/26/securing-the- energy-supply-chinas-malacca-dilemma/. 
Hannah, H. I. (2019, March 31). The Great Game Moves to Sea: Tripolar Competition in the Indian Ocean Region. Retrieved from https://warontherocks.com/2019/04/the-greatgame-moves-to- sea-tripolar-competition-in-the-indian-ocean-region/

Kuper, Stephen. "Chinese Navy Port Call Raises Eyebrows and Concerns." Defense Connect Defence Industry News and Analysis. Last modified June 4, 2019. https://www.defenceconnect.com.au/maritime-antisub/4165-chinese-navy-port-callraises- eyebrows-and-concerns.

Melvin, Neil. "The Foreign Military Presence in the Horn of Africa Region." SIPRI. Last modified April 2019. https://sipri.org/sites/default/files/2019-04/sipribp1904.pdf.

Ministry of Foreign Affairs of the People's Republic of China. Foreign Ministry Spokesperson Hong Lei's Regular Press Conference. Beijing: Ministry of Foreign Affairs of the People's Republic of China, 2016. https://www.fmprc.gov.cn/nanhai/eng/fyrbt_1/t1333741.htm.

Ministry of National Defense of the People's Republic of China. Defense Ministry's Regular Press Conference on Feb.25. Beijing: Ministry of National Defense of the People's Republic of China, 2016. http://eng.mod.gov.cn/Press/201602/25/content_4644801.htm.

Ministry of National Defense of the People's Republic of China. (2015). White Papers. Retrieved from Ministry of National Defense of the People's Republic of China website: http://eng.mod.gov.cn/Database/WhitePapers/

Nincic, Donna J. "Troubled Waters: Energy Security as Maritime Security." Presentation, Post Naval Graduate School, n.d.

Pike, John. "Djibouti - China Naval Base." GlobalSecurity.org. Last modified February 6, 2018. https://www.globalsecurity.org/military/world/djibouti/forrel-prc-base.htm.

Regarda, Helena. "China Global Security Tracker, No.5." International Institute for Strategic Studies. Last modified August 1, 2019. https://www.iiss.org/blogs/researchpaper/2019/08/china- security-tracker-jan-to-june.

Samaranayake, Nilanthi. "Bangladesh's Submarines from China: Implications for Bay of Bengal Security." Startseite - CSS - Center for Security Studies | ETH Zürich. Last modified December 6, 2016. https://css.ethz.ch/content/dam/ethz/specialinterest/gess/cis/center-for- securities-studies/resources/.pdf.

Stockholm International Peace Research Institute. New Report on the 21st Century Maritime Silk Road. Sweden: Stockholm International Peace Research Institute, 2018. https://www.sipri.org/news/2018/new-report-21st-century-maritime-silk-road.

The State Council Information Office of the People's Republic of China. China's National Defense in the New Era. Beijing: Foreign Languages Press Co. Ltd., 2019.

The State Council Information Office of the People's Republic of China. Full Text: China's Military Strategy. Beijng: The State Council Information Office of the People's Republic of China, 2015. 05/26/content_4586805_4.htm.

http://eng.mod.gov.cn/Press/2015-

Yonghong, Dai. Rivalry and Cooperation: A New "Great Game" in Myanmar. Stockholm: Institute for Security and Development Policy, 2014. https://isdp.eu/content/uploads/publications/2014- yonghong-rivalry-andcooperation-a-new-great-game-in-myanmar.pdf. 